\title{
Psycho-Pedagogical Requirements of Methodical Apparatus in the Textbooks of Albanian Language and Literature
}

\author{
Mirela Dimo (Çepele) \\ "Kristal" University \\ Email: mireladimo1@gmail.com
}

Doi:10.5901/mjss.2014.v5n20p2368

\begin{abstract}
The methodical apparatus is a necessary point, where we can analyze what we have explained, and what the student has learned. It is known that during the questioning, the teacher's work focuses mainly on the assessment of students' knowledge, but is important that the teacher with his questions to develop critical and creative thinking skills of students. Student at the end of the lesson should reach to analyze, interpret, discuss, explain, compare and observe. So, if he arrives to perform these actions within a teaching lesson, that is more important, then we can say that we have achieved a successful teaching lesson. What is the evidence that proves that the student has managed to receive complete information during explanation of new knowledge? The best proof is pedagogical or methodical apparatus, which forms the basis of the implementation of learning logical, activation in higher degree of students. It is the mechanism that directs and guides, as a platform clear, link between the trio: teacher- literary part-student.
\end{abstract}

Keywords: methodical apparatus, contemporary teaching, critical thinking, creative skills

\section{Introduction}

Literature modernisation, the developed teaching that relates to a another very important link, that initially starts with the design of texts and then actively and creatively unbundling and methodical apparatus or pedagogical realization forms the basis of learning logical activation in the higher reflective, critical and creative to student. Is the mechanism that directs and orients under a clear platform connection between the trio: Teacher - part literary - student.

If this mechanism will not perform properly this raport, other text and classes literature is failed. Teacher and our schools today requires, phase primary, towards a conception of the role it should play in activating methodical aids students in promoting him as the sense and logic, as the emotion as well as the critical reflection.

Role and methodical apparatus philosopher should see a sense of organically made. So the transformation of scientific values in the value ideo-artistic. This sense, device is a methodical scientific text it self and the specific requirements of criterion joining methods, psychological, sociological, aesthetic, conceptual, linguistic, research argumentative, reflective, critical, etc.., and staying close the literary text with clearly goals. Very success of this important link that organizes all the class, begins at conception initially in a fresh way by modern methods of connections to be created between teachers and students on the one hand, and part literary students from two directions. These two directions to be guided by internal logic that prevails respect and dependence reason-consequence at all levels of the methodical apparatus (in itself and each of transition from one lesson to another).

The challenge of curriculum specialists and school textbooks is to create visions of the future and to adapt for the schools and their programs to these visions, in order that actualized curricula to serve the needs and the members desires of the school and

society (Orstein, Alan C. 2003).

All this requires an organization of teaching on a new and contemporary mentality, during the work with methodical apparatus which facilitates the learning of the students and:

- Develops students' skills in the subject of literature, to realize a critical learning, creative and independent.

- Develop initiative and independence in decision making, the analysis of the characters, in comments and discussion inside and outside class.

- Encourage diversity in student learning and creativity in the literary and aesthetic constant perfection.

- Develop better communication skills, develop management skills, organizational, cooperative, etc., where the prime example and model introduces teacher. 
- Develop big spaces for creative and imaginative thinking, and to practice skills in a higher degree of scientific knowledge.

\section{Theoretical and Practical Look - Building Questions of the Methodical Apparatus According to Levels of the Bloom Taxonomy}

Teaching for the development of critical and creative thinking is not a simple task, nor a task that can be performed in a certain class and then forgotten. There isn't a cut sequence of steps to be followed to lead to critical thinking, which encourage the development of critical thinkers, thus turning the students in "Knowledge builder or critical thinkers"(Ch. Temple, A. Crawford, W. Saul Mathewus S, 2006).

One of the important factors, is strictly methodical apparatus. Always precede a dilemma that who should write it, but have quietly accepted that a teacher is always the best author for methodical apparatus. It is he who has to work with to build a teaching lesson and that the latter to be more successful, the teacher and the student should be merged into a single, where to dominate conversation, discussion and the update and contemporary learning process with modern teaching methodology with the student center.

As such, the methodical apparatus should play two functions: to serve the teacher, but and the students. Teachers too often, uses the apparatus as support for the new subject and to ask students. But, on the other hand, the methodical apparatus serves and for the students, where they supported to understand and bring important learning points. The methodical apparatus, seen from this perspective is an important link and should not be overlooked.

At the time of construction of a text should be think for one methodical apparatus as effective, which help the teacher to explain the lesson. The methodical apparatus shuld built to help our teachers not only experienced, but younger ones for whom this is a support apparatus in their new experience.

Every text has a methodical apparatus that periodically repeated from one lesson to another. This section can be found labeled at different forms as: (Guidelines for textbook publishers, 2008):

$>$ Questions and tasks.

$>$ Stop and discuss.

$>$ Divide between you.

$>$ Answer the following questions etc.

These columns supported in question or series of questions, which aim to establish a relationship between the student and what he has learned from the text during teaching unit. Generally, questions operate with Bloom's Taxonomy (hierarchical classification of learning objectives by three domains: cognitive, affective and psychomotor, starting from the lowest level which is recognition to the highest level that is assessment) and attempting to verify at every student, memory, reproductive ability of the knowledge gained, comparative, analytical skills, etc.

One of the best systems for the classification of questions, according to the degree of difficulty of recognition, is the Bloom's Taxonomy (Musai, 2003). This system has the advantage to provide a broad space for the construction of questions, ranging from those requiring simple reproduction to those that promote higher thinking processes (Musai, 1999). This variety of questions building at all levels of thinking with varying degrees of difficulty, is part of the art of questioning and of the construction of the methodological and methodical apparatus of literature text at any level of education.

\begin{tabular}{|c|c|c|}
\hline $\begin{array}{c}\text { The level of } \\
\text { behavior's difficulty }\end{array}$ & The expected behavior of the student & Teaching process \\
\hline $\begin{array}{l}\text { Acquaintances } \\
\text { (reproduction) }\end{array}$ & $\begin{array}{l}\text { The student is able to recall or reproduce information, to recognize facts, rules and } \\
\text { terminology. }\end{array}$ & $\begin{array}{l}\text { Repetition } \\
\text { Reproduction } \\
\text { Definition } \\
\text { Description } \\
\text { Identification }\end{array}$ \\
\hline $\begin{array}{l}\text { Understanding } \\
\text { (sense) }\end{array}$ & $\begin{array}{l}\text { The student is able to change the form of communication, transforming and } \\
\text { redefining what is read, or is spoken. }\end{array}$ & $\begin{array}{l}\text { Explanation } \\
\text { Illustration } \\
\text { Summary } \\
\text { Circumlocution } \\
\text { Reformulation }\end{array}$ \\
\hline $\begin{array}{l}\text { Application } \\
\text { (transfer) }\end{array}$ & $\begin{array}{l}\text { The student is able to apply the learned information in a content differrent from that } \\
\text { previously used. }\end{array}$ & $\begin{array}{l}\text { Practice } \\
\text { Transfer } \\
\text { Implementation }\end{array}$ \\
\hline
\end{tabular}




\begin{tabular}{|c|c|c|}
\hline & & $\begin{array}{l}\text { Use } \\
\text { Commitment }\end{array}$ \\
\hline Analysis (link) & $\begin{array}{l}\text { The student is able to share the problem in its constituent parts and to establish } \\
\text { relationships between the parts. }\end{array}$ & $\begin{array}{l}\text { Generalized trial } \\
\text { A separate trial } \\
\text { Link } \\
\text { Difference }\end{array}$ \\
\hline Synthesis (creation) & $\begin{array}{l}\text { The student is able to combine the parts to form a particular or a new solution of one } \\
\text { problem. }\end{array}$ & $\begin{array}{l}\text { Ramification } \\
\text { Generalization } \\
\text { Statement } \\
\text { Composition } \\
\text { Production }\end{array}$ \\
\hline Evaluation (trial) & $\begin{array}{l}\text { The student is able to make decisions about values or available methods, ideas, } \\
\text { people or products, according to previously established criteria. }\end{array}$ & $\begin{array}{l}\text { Differentiation } \\
\text { Conclusion } \\
\text { Evaluation } \\
\text { Decision } \\
\text { Excuse }\end{array}$ \\
\hline
\end{tabular}

\subsection{Application "Acquaintances Level"}

Acquainting requires from the student to reproduce, describe, define or recognize the facts that he knows and are recorded in his memory. Some of the active verbs that can use the teacher, to formulate questions at this level are: Define, describe, identify, order, names, reproduce ..., etc.

- What calls Konica true literature (Petro, Meniku, Marashi, 2010)?

- Who are the writers who mention Konica?

Each question requires accurate answer, only reproducing facts previously recorded in memory. They do not require an understanding of what the student has registered in memory, as well as the ability to use learned facts in a situation of solving in the problem- in question.

The teacher should always ask the question oneself: Are the facts that I'm giving students to learn, related to their previous knowledge? If this question becomes steadily, then will be avoided by the teacher questions that may require inappropriate or unnecessary knowledge.

\section{Types of Activities and Skills that Develop when Working with Methodological Apparatus in Literature Subject}

According Xh.M.De Ketel (Fransua, Mary Zherar, Ksavje Rozhje, 2003) have these skills:

$>$ Repetitive skills are those aspects of operations, which consist of skills to repeat, or to reproduce that knowledge, previously embraced or taken at that point without distorting their meaning.

> Cognitive Skills (Fransua, Mary Zherar, Ksavje Rozhje, 2003) are more developed aspects of the activity, related to the recognition process, that is to say that are those aspects of the activity, which require some cognitive effort, led to the transformation of clear or secret information. In the first place this regards "based cognitive activity", so as to enable the basic concepts distinguishing the concepts of second hand. These aspects of the activity, primarily used in those situations, which in structure, differ from situations where they are displayed for the first time. This area is the subject of several taxonomic classifications (Fransua, Mary Zherar, Ksavje Rozhje, 2003), from which we can mention Bloom classifications (Bloom - D'Hianaut 1956 1983).

> Psychomotor skills, represent itself aspects of the activity, where dominates the physical action that requires kinetic control. Psychomotor skills vary from mimetic skills, because the situations that require their use, differs from the initial situation, which poses the most difficult requirements than simple repetition. This area is also the subject of taxonomic classifications, particularly of Simpson (Simpson - 1966) and Harroy (Harrow - 1972).

$>$ Affective skills (behavior) - are those internal and external forms of behavior, with the help of which, the individual displays his worldview (self understanding, self assessment, the worldview of those who surround and furthermore the perception of different life situations, through which react and act. Should be noted, that these three different forms of expressions are mutually linked and can not be studied separately from each other. 


\section{The Table below Presents Several Activities for Various Items of Learning in the Subject of Literature}

\begin{tabular}{lllll}
\hline $\begin{array}{l}\text { The replay } \\
\text { skills }\end{array}$ & Repeat verses of the poem Repeat the definition of poetry $\begin{array}{l}\text { To determine the five stages } \\
\text { through which has gone the } \\
\text { development of poetry. }\end{array}$ & $\begin{array}{l}\text { Describe ... } \\
\text { Repeat ... }\end{array}$ \\
\hline $\begin{array}{l}\text { The cognitive } \\
\text { skills }\end{array}$ & $\begin{array}{l}\text { Enumerate the basic ideas } \\
\text { and views through detailed } \\
\text { references in the text. }\end{array}$ & $\begin{array}{l}\text { The set time limits on the extent } \\
\text { of romanticism. }\end{array}$ & $\begin{array}{l}\text { To analyze the substance or idea } \\
\text { of poetry. } \\
\text { narrative structure } \\
\text { of the text. }\end{array}$ \\
$\begin{array}{l}\text { Psychomotor } \\
\text { skills }\end{array}$ & $\begin{array}{l}\text { Identify by interpreting } \\
\text { passages of the work. }\end{array}$ & $\begin{array}{l}\text { Show the positive and negative } \\
\text { aspects of the literary work. }\end{array}$ & $\begin{array}{l}\text { To present schematically kind of Interpret and recite } \\
\text { poetry that developed during } \\
\text { romanticism. }\end{array}$ & $\begin{array}{l}\text { the verses of the } \\
\text { poem. }\end{array}$ \\
$\begin{array}{l}\text { The affective } \\
\text { skills }\end{array}$ & $\begin{array}{l}\text { Adopt the skill of using the } \\
\text { dictionary to determine the } \\
\text { meaning of a new term. }\end{array}$ & $\begin{array}{l}\text { Determine situations from } \\
\text { everyday life, in which can be } \\
\text { used literary concepts of } \\
\text { meanings. }\end{array}$ & $\begin{array}{l}\text { Express through a free writing } \\
\text { their views on the main } \\
\text { character. }\end{array}$ & $\begin{array}{l}\text { To understand the } \\
\text { feelings of people } \\
\text { around. }\end{array}$ \\
\hline
\end{tabular}

According to De Ketel (Fransua, Mary Zherar, Ksavje Rozhje, 2003) there is a high degree of activity: creative skills (creative). These are aspects of the activity, requiring skills in work involvement, project processing, planning, realization, evaluation, the consensus in our case on the subject of literature.

\begin{tabular}{lllll}
\hline $\begin{array}{l}\text { The creative } \\
\text { skills }\end{array}$ & $\begin{array}{l}\text { Provides information on the } \\
\text { types of essays. }\end{array}$ & $\begin{array}{l}\text { Ability to express opinions on } \\
\text { different types of essays. }\end{array}$ & $\begin{array}{l}\text { To start writing } \\
\text { a essay. }\end{array}$ & $\begin{array}{l}\text { To realize the staging of the } \\
\text { dramatic show. }\end{array}$ \\
\hline
\end{tabular}

Creative habits include in all we described (repetitive, mimetic, cognitive, affective and psychomotor skill). Developing creative skills also implies the ability to generalize, to evaluate the results, to compare, which condition the appearance of dynamic self which is often defective in schools.

\section{Results}

With literature text-books that focus on outcomes and results expected not only in pure knowledge, facts and available information, but also in the development of attitudes and values, it has begun to reach out to the students through questions and tasks, that according to the level of difficulty, in most textbooks appear in different knowledge levels and not just simply in the level of reproduction. Ways of developing the questions and tasks in Albanian language and literature textbooks gives students space to take an initiative, be able to come to the conclusion themselves and in the judgments of individual and group, putting them in the position of requesting and researchers for to reach the necessary and essential information. There are such case when questions are drawn at the level of simple reproduction, which require correct and directly answers that the student, without trouble will find them available on the text but this satisfies then the part of tasks to which present different interactive situations, maintaining students active and leaving him the space to figure out different information sources to achieve the desired result.

What remains to be done in the future, in both levels of schooling is such less information, or only qualitative and essential information and as many parts in which encourage communication through interaction, images, illustrations, photographs, and similar situations, which may help pupils to be always active part of the learning process.

Positive changes that are visible in textbooks require changing the methodological work of teachers, so that they can be transmitted in order better to those for which it is conceived text-book the student then our practice school, is not only school main source, but also the only one this learning.

There are few cases in which the teacher goes for beyond textbook to reach the desired result.

The number one person is the teacher who gives life changes, other no doubt that his role in teaching process is extraordinary and irreplaceable.

Modernization of our society, with the most scientific and positive understanding has requested in the first place, so necessary modernization of developed teaching to learning; the construction of text-book; redesigning methodical apparatus developed teaching methodology that are not only contemporary requirements, but important psychomethodical problems of teaching and learning on the whole. 


\section{References}

AEDP (1998) Study everything, the reason the first place. (Collection of articles)Tiranë.

AEDP (2000) Guidelines for the development of critical thinking through literacy.

Ch. Temple, A. Crawford, W. Saul Mathewus S, (2006) Strategies for teaching and learning for thinkers classes, CDE, Edition of the Project "Developing critical thinking in reading and writing":

Fransua, Mary Zherar.Ksavje Rozhje. (2003). "Design and evaluation of textbooks. Developing pedagogy. Methodologies practice" Tiranë.

Guidelines for textbook publishers "Gender perspective in textbooks". (2008).

Karamitri, E. Petrit, K. Murthi, L. Pepa, V. (2001) Literature in school. AEDP. Education Development Project in Albania. Tiranë.

Musai, B. (1999) Psychology of education, Development, Learning, Teaching. Tiranë. Pegi.

Musai, B. (2001) Models for successful teaching. Tiranë

Musai, B. (2003) Teaching methodology. Tiranë: Pegi.

Orstein, Alan C. (2003) Curriculum, Fundamentals, Principles and problems. Tiranë: ISP.

Petro, R. Meniku, L. Marashi, A (2010) Albanian Language and Literature 11. Albas School Publishing.

QTKA. (2005). Student -Centered Teaching. Tiranë. 